\title{
From semiosis to social policy: The less trodden path
}

\author{
Andrew Stables \\ Department of Education, University of Bath \\ Bath, BA2 7AY, United Kingdom \\ e-mail: a.w.g.stables@bath.ac.uk
}

\begin{abstract}
The argument moves through three stages. In the first, the case is made for accepting 'living is semiotic engagement' as 'a foundational statement for a postfoundational age'. This requires a thoroughgoing rejection of mind-body substance dualism, and a problematisation of humanism. In the second, the hazardous endeavour of applying the above perspective to social policy begins with a consideration of the sine qua non(s) underpinning such an application. These are posited as unpredictability of outcomes and blurring of the human/non-human boundary. In the third stage, the case is developed for a policy orientation that is both liberal-pragmatic (with some caveats relating to 'liberal') and post-humanist, and the paper concludes with some speculation concerning the precise policy outcomes of such an orientation.
\end{abstract}

\section{A fully semiotic perspective}

Most work in cultural and social semiotics examines existing practices through a semiotic lens. It is a strategy less often attempted to start from a perspective of practice as 'semiotic' (or 'semiosic') and to extrapolate from this to real-world application. As a philosopher of education, I have attempted to do this in a series of recent publications (Stables 2006a; 2006b; Stables, Gough 2006). In this paper, I shall attempt to answer the question, 'What implications does a fully semiotic view of living have for the development of social policy?' However, I must begin by justifying the assertion that 'living is semiotic engagement', and attempt to clarify where such an assertion sits in relation to existing biosemiotic and pansemiotic perspectives. 
The term 'semiotic' is a little problematic here, in two respects. Firstly, it relates both to semiosis (the act of responding to signs) and to 'semiotics' (implying, in some cases, but not others, meta-awareness of sign use - as in the work of Maran, e.g. 2003). I intend the first of these uses, aware that the more rarely used term 'semiosic' has been adopted by some commentators for this purpose (e.g., Hoffmeyer 1995b).

Whatever meta-awareness actually is (for it has certain connotations of 'mind' that I shall challenge below), I can neither prove nor disprove that it is a propensity common to anything beyond the human (cf. Nöth's distinction between homo semioticus and organismus semioticus in Nöth 1998: 332). However, this issue becomes redundant if the second problem is addressed satisfactorily. This (the second problem, though related to the first) is that the semeion - the sign is traditionally reckoned to be something transmitted by a purposive meaning-maker; this despite extensive Twentieth Century debunking of the assumption that a 'text' is simply the product of an 'author' (e.g., Eagleton 1983, for an overview of the arguments, and Barthes 1977). On this assumption of purposive meaning-making, the view that this paper develops of all living as semiotic engagement would be the kind of pansemiotic view suggested by Nöth (1998), in which all life is construed as a series of divinely inspired messages, but this is not the line I shall be taking as I do not accept this author-dependent view of the sign. (This is not to preclude the possibility that people will interpret all they perceive as messages from God, of course, or even that such an interpretation is necessarily invalid.)

Rather, my use of 'semiotic' here is one that interprets the semeion as both 'sign' (intended or otherwise, and evidently value-laden), and as 'signal' (as morally, or evolutionarily neutral 'prompt'). ${ }^{1}$ In other words, I do not distinguish between signs and signals on the basis of a commonly discredited Cartesian substance dualism that unjustifiably divides 'mind', conscious or otherwise, from 'matter', or that merely chooses one over the other: a solution that fails adequately to dissolve

\footnotetext{
1 In Stables 2006a; 2006b; Stables, Gough 2006, I have employed the term 'sign(al)' to this end. (For a biosemiotic perspective according to which DNA carries survival messages of evolutionary value, see Sharov 1998; Sharov's perspective is explicitly biosemiotic rather than pansemiotic, however: on Sharov's view, the DNA carries messages of survival value that distinguish the living from the non-living.)
} 
the dualism since it continues to beg interpretation of each term in light of its opposite (i.e. matter as mindless; mind as supernatural). By implication, therefore, mine is a pansemiotic perspective in the broader sense suggested by commentators on Peirce (as contrasted with anthroposemiotic and biosemiotic perspectives by - for example - Emmeche 1999) rather than in the narrower sense alluded to above: it is possible to see all activity semiotically/semiosically and impossible ever to be sure what, if anything, precedes the sign. It differs from a biosemiotic view such as Sharov's (1998) in begging the problematisation of the living $v s$. non-living divide as well as that between the human and the non-human; it makes no prior ontological assumptions. Maran (2006), for example, cites Hoffmeyer (1995a) stating 'that the simplest entity with full semiotic competence is a single cell'. On my account, while cells can indeed be construed as acting semiotically (see below), this may not be the end of the story. However, for the purposes of the present argument, with its focus on social policy implications, it is necessary merely to acknowledge that a 'fully semiotic' perspective deconstructs the boundaries of the human - a point that will be developed in a later section.

In a recent article, I summarised my argument as follows:

If there is body and soul - mind and matter - then the difference between 'signs' and 'signals' [...] is a crucial one. Mental, spiritual, conscious human beings communicate via signs, as uniquely gifted symbol users; other animals, even cells and genes emit and respond to signals.

We $[\ldots]$ live by emitting and responding to either signs or signals - and, as we cannot be sure about whether mind and matter are really separate, we cannot be sure of the validity of dividing signs from signals, hence my rather clumsy neologism, the sign(al) - and, if this makes sense, then the statement 'living is semiotic engagement' is, potentially, a foundational statement for a post-foundational age. That is to say, we could usefully begin our studies of all sorts of things in the human sphere with a realization that messages - be they laws, political ideologies, teachers' explanations or even medicines or physical punishments - are received and acted upon differently by people and are always understood in the light of their previous experience. (Stables 2006b: 374-375)

All living, therefore, can be understood as semiotic engagement, provided: (1) we do not distinguish between signs and signals, (2) we do not regard all sign(al)s as consciously transmitted, and (3) we do not differentiate between a 'mind' that processes 'signs' and a body (in the broadest sense) that responds unthinkingly to 'signals'. These 
criteria can be met if we do not distinguish between mind-substance and body-substance: in other words, if we reject Cartesian dualism.

On this account, thought, feeling and action are all forms of human behaviour; perhaps non-human also. Reasoning is one of the things we do; sleeping is another. Human fulfilment entails enjoyment of each of these kinds of activity, and of many more beside. We do not need an unsustainable concept of dualism to work on this basis.

Of course, 'semiotic engagement' is one of several possible descriptors for human life (putting aside the non-human issues for a moment). It is also possible to construe living as a Darwinian fight for survival, an essentially meaningless state for which we have to invent a meaning, after Nietzsche, Sartre and the existentialists, or as the working out of a divine plan. Each of these perspectives, too, can be used as a basis for social policy. However, as such a basis, all three demand that each citizen 'buy in' to the prevailing view to some extent. A construal of living as semiotic engagement has as its starting point that everybody will see the world to some extent differently; it can incorporate the other views, acknowledging, inter alia, both competition and co-operation as essential elements of our Umwelten (Uexküll 1982), accepting a notion of life as narrative without assuming that any narrative is simply the product of an author, and allowing for both religious and secular interpretations (provided one does not attempt to preclude the other). On this view, outcomes are uncertain, but they will certainly be arrived at through a process that can validly be described as semiotic, or semiosic, in the terms given above.

\section{Semiotic engagement as reading and writing: Implications for policy}

The question arises as to whether this 'foundational statement for a post-foundational age' is any more than a truism. To examine its implications for social policy broadly, it may be helpful to return to a context in which people are used and content to take a semiotic perspective: that of response to literature, film and works of art.

Reading a book involves responding, half-consciously, to a complex, evolving series of signs, in terms both of their incontrovertible denotations and their endlessly varied connotations (though 
note that the distinction between denotation and connotation is problematised outside a realist epistemology, where no sign either simply 'stands for' something nor does anything other than evoke something that it is not). Texts operate on a spectrum characterised by Barthes as from 'readerly' to 'writerly' according to how open they are to multiple interpretation. However, when the response to text is taken to include subsequent action, it becomes clear that no text, however simple and apparently ambiguous, is closed to interpretation; it is impossible to prescribe how people will respond to any text. (Consider the variety of responses to a speed restriction sign on a road, for example.)

Insofar as living is both textual and intertextual, therefore - as a fully semiotic perspective takes it to be - human responses, on all fronts, are always somewhat unpredictable. Signs are received in context, and context always varies; thus response to signs and combinations of signs always varies. Interpretation is inevitable, therefore, even without any conception of autonomous human 'mind'. This is the first major implication of a fully semiotic view of living for social policy: outcomes are unpredictable. By further implication, rational social planning is an inexact and potentially hazardous art, since the outcome of any social policy is also unpredictable. ${ }^{2}$

The second, related implication is that all systems are open systems, just as all texts are intertextual. Any institution, for instance, understood fully semiotically, is a network of meanings, an 'imagined community' in 'discursive space' (Stables 2003a; 2003b), a complex and evolving text constantly countersigned (e.g., Derrida 1992) and modified by the behaviour of those relating to it. Thus there are no firm boundaries to any institution or other form of social system; even outsiders are effectively insiders since, by merely knowing about any institution (in any way at all), they affect it through their actions, words and attitudes. Thus what everybody thinks and does changes the world, albeit there are no grounds for claiming that each person's actions do so 'equally'.

If there are no firm boundaries to anything, there are no firm boundaries to humanity: a fully semiotic perspective blurs the humannonhuman divide (and may also blur the life-nonlife divide, and thus

\footnotetext{
2 Students never learn quite what teachers teach; no form of social provision ever quite delivers the goods it was intended to deliver; aims are expressions of wishes but are not precisely achievable.
} 
the tensions between biosemiotic and pansemiotic perspectives, though that is not the direct concern of this paper). In relation to this, it can no longer remain tenable to define the human condition by a series of exclusive attributions, including those of 'language' and 'feelings'. This is not tantamount to claiming that sheep speak English (as Sebeok, 1995, has pointed out, there is no evidence of anything beyond the human using syntactic structures, as we understand them), but amounts simply to a claim that the general kinds of behaviour, including mental operations relating to spatial awareness, recognition, tool use and memory, that classical humanists and many of a religious persuasion have been used to seeing as unique to the human species, can be found in other life forms. What it means to be human is thus problematised by a fully semiotic conception of living.

The sine qua non(s) of social policy from a view of living as semiotic engagement would seem to be, therefore, that policy-makers have power to affect what happens, but not to predict it (so social policy should be limited and pragmatic in its aspirations), and that human interests cannot be firmly demarcated from non-human interests. These are bases for social policy that take a strongly relational view, and are therefore necessarily ecosemiotic (Kull 1998; Nöth 1998), but that also discourage social engineering. For these two reasons, I refer to my political position as one of post-humanist liberal pragmatism. ${ }^{3}$

My position is post-humanist insofar as it both builds on and moves beyond humanism, as postmodernism both builds on and moves beyond modernism. Indeed, as postmodernism rejects a simple historical view of history, but rather sees the postmodern as a recurrent voice within the discourse of modernity (Lyotard 1984; 1988), so post-humanism can be understood as immanent critique of humanism, finding its voice in aspects of, for example, Romanticism and deep ecology. It relates to conceptions of narrowness in humanist conceptions of flourishing.

I am aware of the irony of this in the context of the indebtedness of the development of semiotics to cultural Marxism, and even their mutual independence. I look forward to a Marxist critique of my argument. 


\section{Beyond both humanism and cyborg posthumanism}

Contemporary 'Western' culture is essentially humanistic. Both the Renaissance and the Enlightenment were driven by a belief in human potential and the specialness (even the divinity) of the human condition. Human life has been endowed with a value (a preciousness, some might say) that justifies the subservience of the rest of nature to human needs. Thus human beings must be fed, clothed, housed, educated and supported at all costs, and human life must be preserved at all costs. This worldview is still critiqued more for its failure to achieve these objectives than for its treatment of non-human life in pursuing them. So deep-rooted is this belief system that we are all myself included - loath to depart from it lest we open the door to indiscriminate cruelty, neglect and barbarism. Even 'sustainable development' is largely conceptualised as 'social development' despite its genesis in the ecological movement; humanism has largely triumphed over environmentalism, perhaps.

Nevertheless, this pursuit of (short-term) human flourishing at any cost is clearly limiting. Increasing the wealth, warmth and health of a burgeoning human population entails - or has tended to entail - the depletion of natural resources, the reduction of biodiversity, the pollution of non-human places, and the possible destruction of the entire ecosystem as a result of increased and no-longer-controllable global warming caused by greenhouse gas (especially carbon dioxide) emissions. Already the tropical rain forest (that which remains of it) is becoming subject to fire and the ice caps are beginning to melt. I read in a newspaper recently that each square mile of ocean contains tens of thousands of items of human rubbish, and that chemicals in arctic waters are causing medical and genetic problems for a range of species. There are two possible responses to this: either to seek a nonhumanistic, anti-humanistic values base, with all the attendant dangers of deciding that human life is not (effectively) sacrosanct - which, after a century of ethnic cleansing, would be as sensible as jumping into a pond full of crocodiles - or to adapt humanistic values to a situation in which human wellbeing is never considered apart from non-human thriving, and the endless relations of the human to the non-human are never disregarded. This is the harder path to follow, but surely the only one that holds any real hope for the future. It is this 
kind of posthumanism, entailing an extension, rather than a curtailment of humanist values, that I propose.

Ironically, however, much of the existing literature sometimes considered posthumanist pays little or no heed to the non-human per $s e$, but rather focuses largely on problematising the human condition via the implications of (human) technology: considering, for example, the 'cyborg' nature of the human, dependent largely on the machine (Haraway 1991; Hughes 2004 — though Haraway also considers the human-animal interface), sometimes substituting 'transhuman' for 'posthuman'. Such perspectives are of considerable interest to both philosophers and casual conversationalists (for instance, how much of yourself could be replaced by artificial organs before you stopped being human, or having human rights? Is your humanity enhanced by hearing aids or spectacles?) as they are of perennial fascination to writers of science fiction, but they are not primarily focused on the issue of human survival in the context of global survival, albeit they contain many relevant and important insights. The ecosystem is greater than the human system, however defined.

Thus it is not enough to blur the boundaries of what it means to be human, if by doing so we are concerned merely with redefining what it means to be human, though this is part of what any useful posthumanism must entail. The human relationship with the (utterly) nonhuman is also very important. Implicit in any blurring is the issue of manifold relatedness, and implicit in issues of relatedness are issues of ethics. Ethical issues are certainly human issues, but they cannot be resolved by examining human issues in isolation. This is a lesson we are beginning to learn, but slowly. A fully semiotic view of living renders the necessary move a little easier by undermining some assumptions of qualitative difference between human and non-human.

\section{From theory to policy}

Detailed discussion of specific policy areas is not possible here (though see Stables 2003a; 2006a for examples relating to education). However, it may be instructive to consider one case of almost universal interest in which humanist assumptions could be both adopted and extended: that of the provision of housing. In countries such as England, there has been significant immigration in certain 
areas, while other social factors such as family breakdown have also increased demands for housing. The South-East of England (the London area) now faces pressure for a huge increase in housing stock at the same time as increasing water shortages and other environmental and infrastructural problems (e.g. traffic congestion). The traditional, humanist response has been to argue that more homes must be built, positing human need as the sole, rather than the greatest priority. A post-humanist response might be that people must be housed but only in the context of an improved (as opposed to depleted) natural environment. Development plans must therefore aim to reduce the 'carbon footprints' of communities, increase biodiversity and reduce the risks of either drought or flooding. This is a demanding aim but not an impossible one: over time, existing settlements could conceivably be replaced by those that were much more ecologically sensitive, just as transport can be made much more environmentally friendly than at present. There are, of course, costs, but they pale into insignificance against the potential costs of continuing the current, narrowly humanist agenda.

Note that my argument is unusual among environmentalists - and perhaps among semioticians - in focusing on humanism rather than capitalism as the major cause of the environmental crisis. This is because humanist values underpin the principal economic systems we recognise: capitalism and socialism. Each exists to maximise human wealth; they differ only over matters of production and distribution. Any post-humanist settlement will be some sort of capitalist-socialist hybrid, but operating on an altered values base. Without that altered values base, both capitalism and socialism will continue to deplete natural resources in the pursuit of increased human wealth. It is not capitalism per se that is to blame for the ecological crisis, but rather human greed and narrow-mindedness. It would, for example, be conceivably possible to operate a capitalist system in which wealth was not taxed at all, but energy use was. Under such an arrangement wealth creation would be valorised but not at the cost of environmental degradation.

There exists the temptation of a relatively easy way to bring such changes about: by reducing individual freedom. Indeed, many environmentalists argue for severe restrictions on (or even reversal of) economic growth, the freedom to travel and live where one chooses, and so on. Luckily (for many environmentalists' ideal communities 
would, I fear, be hells on earth), such prescriptions fall foul of the other tenet of the fully semiotic perspective developed here: outcomes are unpredictable. People will interpret laws and circumstances in different and unexpected ways whether policy-makers want them to or not. Strict social planning does not work. Rather, the more informed the populace is about the complexity of issues, the more chance there is of informed and sensitive private and public action. On this view, the traditional liberal freedoms of travel, assembly, association, belief and speech serve a post-humanist emphasis better than would their restriction (even if we no longer see individuals as autonomous rational agents in the Eighteenth Century manner), since they encourage problematisation, and the challenge for social development is to understand human issues from a more complex set of considerations than hitherto.

This may seem a tentative and highly risky basis on which to construct any policy - yet the management of risk is central to all human endeavour. If policy is to be constructed to further humanistic aspirations while also improving the condition of the biosphere, it will need to respect human life (including human freedom), respect nonhuman life and generally allow for diversity. Thus it is important that policy-makers play their parts in both developing the debate at the highest level (as opposed to 'spinning' themselves away from controversy) and providing the conditions in which that debate can thrive, and actions that might further a posthumanist agenda can be expedited: fiscal conditions, for example, that encourage the development of cleaner technologies and energy conservation, and planning regulations that take more account of general environmental, resource and biodiversity effects (for example, in the current UK context, changing gardens of existing properties from the status of 'brown field' [i.e. developed and easily developable, where applications to build are generally to be allowed] to 'green field' sites [where applications to build are more often to be rejected]).

\section{Concluding remarks}

Have I wandered too far from my starting point? Do the above conjectures and suggestions about policy really derive so self-evidently from a view of living as semiotic engagement? Certainly, many 
semioticians regard themselves as neither liberal nor environmentalist. The line I have taken is entirely dependent on the acceptance that, as Maran and others have suggested, semiosis is a valid construct in relation to the non-human. I suggest that such an acceptance involves a thorough-going rejection of Cartesian dualism that goes further than most existing models. Often, materialist explanations view the universe as mechanical and 'mindless', while panpsychic and certain biosemiotic and pansemiotic explanations regard it as 'minded' in the sense of human, or at least humanly recognisable rational agency. Each of these perspectives is a reaction against mind-body substance dualism, but neither is a complete departure from it. The fully semiotic view I propose seeks to accept that 'what happens happens' without attempting to differentiate between the mental and the physical on a substantive basis. Rather, 'mental' and 'physical' are categories of the same qualitative status as 'oral' (or 'aural') and 'visual'.

The path from such a fully semiotic perspective to the policy debate is one little followed as yet, as there has so far been little detailed application of (other) biosemiotic, ecosemiotic and pansemiotic approaches, and there may be a series of possible alternative routes. In this paper, I have attempted simply to explore the implications of a view of life in which everybody is constantly re-reading and re-writing the world, and in which the idea of semiotic engagement is not merely applicable to humans. This leads me to a set of policyrelated conclusions based on the two premises of (1) the inevitable unpredictability of outcomes, and (2) the continuous dependence of the human on the non-human.

From his biosemiotic perspective, Sharov states:

Biosemiotics brings a new understanding of hierarchies: it does not imply the superiority of a system over its subsystems [...] Human society was definitely evolving from strong systems (monarchies) to weak systems (democracies). (Sharov $1997^{4}$ )

While the present argument is not explicitly biosemiotic in Sharov's terms, the view he appears to be expressing here tallies with my own in construing agents not merely as systems-driven, but rather viewing systems as identifiable abstractions: as relations of agents, who are

4 Sharov, Alexei 1997. Towards the semiotic paradigm in biology. Retrieved from www.gypsymoth.ento.vt.edu/ sharov/biosem/txt/ tosemiot.html 05/07/2006. 
themselves relational entities. Thus society does not precede the individual any more than the reverse; each is in flux, subject to multiple agency. This seems to me to ally strongly a semiotic/semiosic view of living with a political commitment away from state control and pre-specification and towards personal, interpersonal and other forms of interrelational empowerment, and a concomitant emphasis on procedural rather than either retributive or distributive justice, in terms of the reinforcement of those human rights associated with political (not outcome) equality, such as freedoms of conscience and association: in other words, a commitment to political liberalism with a morethan-humanist scope.

\section{References $^{5}$}

Barthes, Roland 1977. The Death of the Author. In: Heath, Stephen (ed. and trans.), Image-Music-Text: Roland Barthes Essays. London: Fontana Press, $142-148$.

Derrida, Jacques 1992. Acts of Literature. London: Routledge.

Eagleton, Terry 1983. Literary Theory: An Introduction. Oxford: Blackwell.

Emmeche, Claus 1999. The biosemiotics of emergent properties in a pluralist ontology. In: Taborsky, Ewina (ed.), Semiosis, Evolution, Energy: Towards a Reconceptualisation of the Sign. Aachen: Shaker Verlag, 89-108.

Haraway, Donna 1991. Simians, Cyborgs, and Women: The Reinvention of Nature. New York: Routledge.

Hoffmeyer, Jesper 1995a. The swarming cyberspace of the body. Cybernetics and Human Knowing 3(1): 16-25.

- 1995b. The semiotic body-mind. In: Tasca, Norma (ed.), Essays in Honor of Thomas A. Sebeok. (Cruzeiro Semiótico 22/25.) Porto, 367-383. ${ }^{6}$

Hughes, James J. 2004. Citizen Cyborg: Why Democratic Societies Must Respond to the Redesigned Human of the Future. Boulder: Westview.

Kull, Kalevi 1998. Semiotic ecology: Different natures in the semiosphere. Sign Systems Studies 26: 344-371.

Lyotard, Jean-François 1984. The Postmodern Condition: A Report on Knowledge. Manchester: Manchester University Press.

- 1988. The Differend. Minneapolis: University of Minnesota Press.

Maran, Timo 2003. Mimesis as a phenomenon of semiotic communication. Sign Systems Studies 31(1): 191-215.

5 Acknowledgements. I am most grateful to Timo Maran, of the Tartu Department of Semiotics, for initiating this paper.

6 An updated version see at http://www.molbio.ku.dk/MolBioPages/abk/ PersonalPages/Jesper/ Semiosic.html. 
- 2006. Where do your borders lie? Reflections on the semiotical ethics of nature. In: Gersdorf, Catrin; Mayer, Sylvia (eds.), Beyond Wild Nature: Transatlantic Perspectives on Ecocriticism. Amsterdam: Rodopi 455-476.

Nöth, Winfried 1998. Ecosemiotics. Sign Systems Studies 26: 332-343.

Sebeok, Thomas A. 1995. Semiotics as bridge between humanities and sciences. In: Perron, Paul; Sbrocchi, Leonard G.; Colilli, Paul; Danesi, Marcel (eds.), Semiotics as a Bridge between the Humanities and the Sciences. New York: Legas, 76-100.

Sharov, Alexei 1998. From cybernetics to semiotics in biology. Semiotica 120(1/4): 403-419.

Stables, Andrew 2003a. School as imagined community in discursive space: A perspective on the school effectiveness debate. British Educational Research Journal 29(6): 895-902.

- 2003b. Education for Diversity: Making Differences. Aldershot: Ashgate.

- 2006a. Living and Learning as Semiotic Engagement: A New Theory of Education. Lewiston: Mellen Press.

- 2006b. Sign(al)s: Living and learning as semiotic engagement. Journal of Curriculum Studies 38(4): 373-387.

Stables, Andrew; Gough, Stephen 2006. Towards a semiotic theory of choice and of learning. Educational Theory 56(3): 271-285.

Uexküll, Jakob von 1982. Theory of meaning. Semiotica 42(1): 25-82.

\section{От семиозиса к социальной политике: непроторенный путь}

Аргументация трехступенчатая. На первой ступени обосновывается положение, согласно которому “жизнь является семиотической связностью” как “базовое утверждение в постбазовую эпоху”. Для этого нужно полностью отвергнуть субстанциональный дуализм между телом и душой и поставить под сомнение гуманизм. Предпринятая на второй ступени рискованная попытка применить данное положение в области социальной политики начинается с подчеркивания необходимости укрепления основ такого применения. Такими основами будут непредсказуемость результатов и стирание грани между человеческим и нечеловеческим. На третьей ступени развивается политическая ориентация, которая одновременно является либерально-прагматической (вместе с некоторыми предупрежденями по поводу либеральности) и постгуманистической. Статья заканчивается размышлениями о реальных политических последствиях подобной ориентации. 
Märgiprotsessist sotsiaalpoliitikani: vähetallatud rada

Argumentatsioon on kolmeastmeline. Esimesel astmel arendatakse vaadet, mis tunnistaks, et 'elamine on semiootiline seostumus', kui 'alusväide alustejärgses ajastus'. Selleks on vaja läbinisti hüljata substantsiline dualism keha ja vaimu vahel, ning seada kahtluse alla humanism. Teisel astmel tehtav riskantne katse rakendada ülalmainitud vaadet sotsiaalpoliitikale algab säärase rakenduse aluste tugevdamise vajaduse rõhutamisest. Neiks alusteks oleksid tulemuste ennustamatus ja piiri ähmastumine inimeseliku ja mitteinimeseliku vahel. Kolmandal astmel arendatakse poliitilist orientatsiooni, mis on ühtaegu liberaal-pragmaatiline (koos mõningate hoiatustega liberaalsuse suhtes) ja posthumanistlik. Artikkel lõpeb mõtisklustega säärase orientatsiooni tegelike poliitiliste väljundite üle. 